\title{
MELTING PHASE RELATIONS OF CHLORINE-BEARING KIMBERLITE AT 2.1-6.5 GPA AND 900-1500 ${ }^{\circ} \mathrm{C}$
}

\author{
Sharygin IS ${ }^{1}$, Litasov KD ${ }^{1,2}$, Shatskiy* ${ }^{1,2}$, Golovin AV ${ }^{1}$, Ohtani $E^{2}$, Pokhilenko NP ${ }^{1}$ \\ ${ }^{1}$ V.S. Sobolev Institute of Geology and Mineralogy SB RAS, Novosibirsk, Russia \\ ${ }^{2}$ Dept. of Earth and Planetary Materials Science, Graduate School of Science, Tohoku University, Sendai, Japan
}

\section{INTRODUCTION}

The important role of chlorine in the formation of diamond and kimberlite melt itself has been argued (Izraeli et al., 2004; Klein-BenDavid et al., 2004; Kamenetsky et al., 2004; Golovin et al., 2007). However, experimental constrains on the formation of deep alkaline magma in the presence of chlorine are still scarce (Safonov et al., 2007; 2009; Litasov and Ohtani, 2009; Litasov et al., 2010a). Udachnaya-East kimberlite (UEK) is a unique example of unaltered group I kimberlitic rocks with high $\mathrm{Na}_{2} \mathrm{O} / \mathrm{K}_{2} \mathrm{O}$ ratio, containing abundant alkali carbonate, chloride, sulphate, and sulphide minerals in the groundmass. (Golovin et al., 2007; Kamenetsky et al., 2007). The study of fluid inclusions in natural diamonds demonstrates that the concentration of chlorine in diamond-forming media may exceed 20-30 wt \% (e.g. Klein-BenDavid et al., 2004).

To understand high pressure melting behavior of chlorine in kimberlite we performed high-pressure and high-temperature experiments on UEK and synthetic $\mathrm{Cl}$ doped $(5 \mathrm{wt} \%)(\mathrm{CDK})$ starting compositions at pressures of 2.1-6.5 GPa and temperatures of $900-1500^{\circ} \mathrm{C}$. New data on the influence of chlorine on crystallization of minerals and the composition of partial melts were obtained that allowed us to make some important conclusions about the origin of kimberlitic magma.

\section{EXPERIMENTAL}

Experiments were performed at pressures of 2.1-6.5 $\mathrm{GPa}$ and temperatures $900-1500^{\circ} \mathrm{C}$ using a multianvil highpressure apparatus at Tohoku University (Sendai, Japan). The octahedral $\mathrm{ZrO}_{2}$ cell was placed in the center of eight cubic WC anvils with $12 \mathrm{~mm}$ truncation edge length. Agraphite tube isolated from a capsule with the sample by the $\mathrm{MgO}$ insulator was applied as a heater. The sample powder was loaded into $\mathrm{Au}-\mathrm{Pd}$ or $\mathrm{Pt}$ capsule and after accurate drying welded by arc welding. The inner walls of Pt capsules were covered by Re foil to minimize iron loss. Each cell contained two capsules: one with the composition of UEK (Table 1) and another with the composition of CDK (see Litasov et al., 2010b for composition). The temperature in each run was controlled by a $\mathrm{W}_{97} \mathrm{Re}_{3}-\mathrm{W}_{75} \mathrm{Re}_{25}$ thermocouple located in the center of the heater and isolated by the $\mathrm{Al}_{2} \mathrm{O}_{3}$ micropipe. The details of pressure calibration and temperature gradient measurements will be reported elsewhere (Litasov et al., 2010b). The composition of phases was determined using electron microprobe at Tohoku University.

\section{RESULTS \\ Udachnaya kimberlite (UEK)}

Observed crystallization sequence of UEK at 4.5 and 6.5 $\mathrm{GPa}$ includes, with decreasing temperature: Al-spinel, olivine, perovskite, Ca-rich garnet, aragonite, and apatite (Figs. 1-2). Clinopyroxene was detected in experiments at 3-3.5 GPa. Experiments at 2.0-2.2 GPa gave controversial results with partial loss of volatiles from the sample capsules and are not considered here. Solidus temperature is located at $950^{\circ} \mathrm{C}$ at $6.5 \mathrm{GPa}$ and below $900^{\circ} \mathrm{C}$ at $3.1 \mathrm{GPa}$.

Liquidus spinel has high $\mathrm{Al}_{2} \mathrm{O}_{3}(40-50 \mathrm{wt} \%)$, FeO (20.5$31 \mathrm{wt} \%)$, and $\mathrm{MgO}(17.5-23 \mathrm{wt} \%)$ contents with subordinate $\mathrm{Cr}_{2} \mathrm{O}_{3}$ (up to $8 \mathrm{wt} \%$ ) and $\mathrm{TiO}_{2}$ (2.6-5.0 wt\%). Olivine has $\mathrm{Mg} \#=89-92$. Perovskite contain high LREE (up to 7 wt.\%) and significant concentrations of HFSE, Th, and $\mathrm{Na}_{2} \mathrm{O}$. Garnet is extremely Ca-rich (26-30 wt\% at low temperatures) and contain up to $6 \mathrm{wt} \% \mathrm{TiO}_{2}$ with increasing T. Clinopyroxene contains $8-9 \mathrm{wt} \% \mathrm{Al}_{2} \mathrm{O}_{3}$.

The melt compositions correspond to $\mathrm{Ca}$-carbonatite (Table 1, Fig. 3-4) and are quite different from those of CDK by high $\mathrm{Na}_{2} \mathrm{O}$ contents. At melt fraction of $20-40 \%$ they contains $<10 \mathrm{wt} \% \mathrm{SiO}_{2}, 22-32 \mathrm{wt} \% \mathrm{CaO}, 8-12 \mathrm{wt} \%$ $\mathrm{Na}_{2} \mathrm{O}, 2.8-5.0$ wt.\%, $\mathrm{K}_{2} \mathrm{O}, 2.0-3.5$ wt $\%$ Cl. Melt compositions are consistent with carbonatite melts formed by partial melting of carbonated eclogite (see Litasov and Ohtani, 2010 for references). Calculated $\mathrm{CO}_{2}$ contents of the melts correlate with the $\mathrm{SiO}_{2}$ contents (Fig. 4).

\section{Cl-doped kimberlite (CDK)}

Preliminary data for CDK system was reported in (Litasov et al., 2010b). Crystallization sequences of CDK at 3-6 GPa include olivine, garnet, clinopyroxene, ilmenite, 


\section{$10^{\text {th }}$ International Kimberlite Conference, Bangalore - 2012}

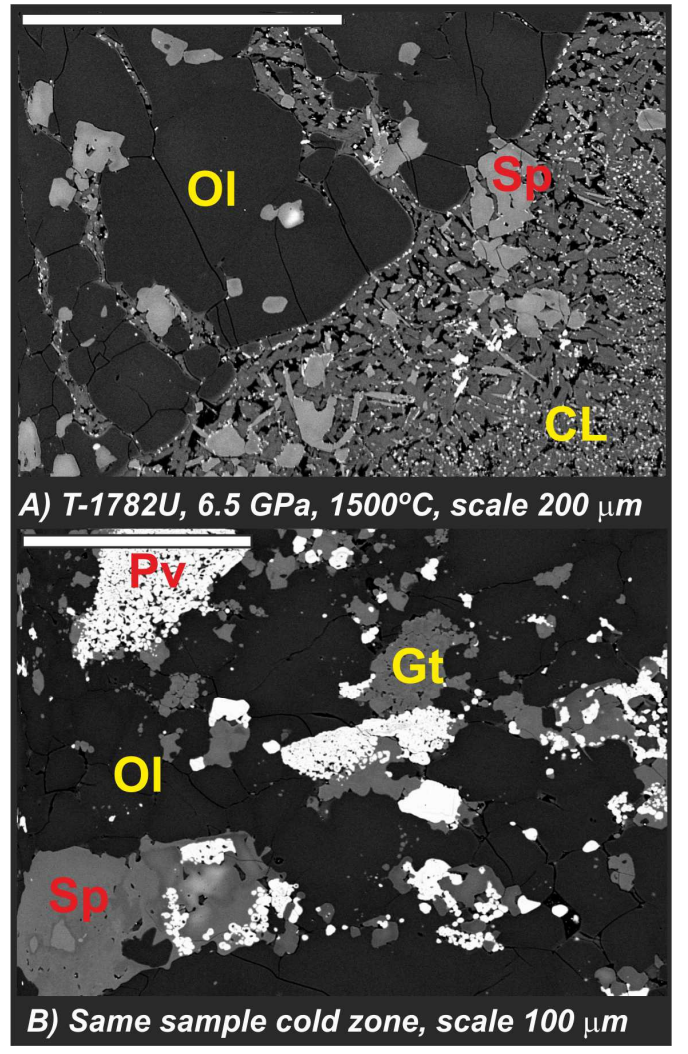

Fig. 1. Back-scattered electron images of UEK sample after experiment. A) Partial melting zone of olivine (Ol), spinel (Sp) and carbonatite melt (CL). B) low-temperature zone containing olivine, spinel, perovskite $(\mathrm{Pv})$, and garnet $(\mathrm{Gt})$.

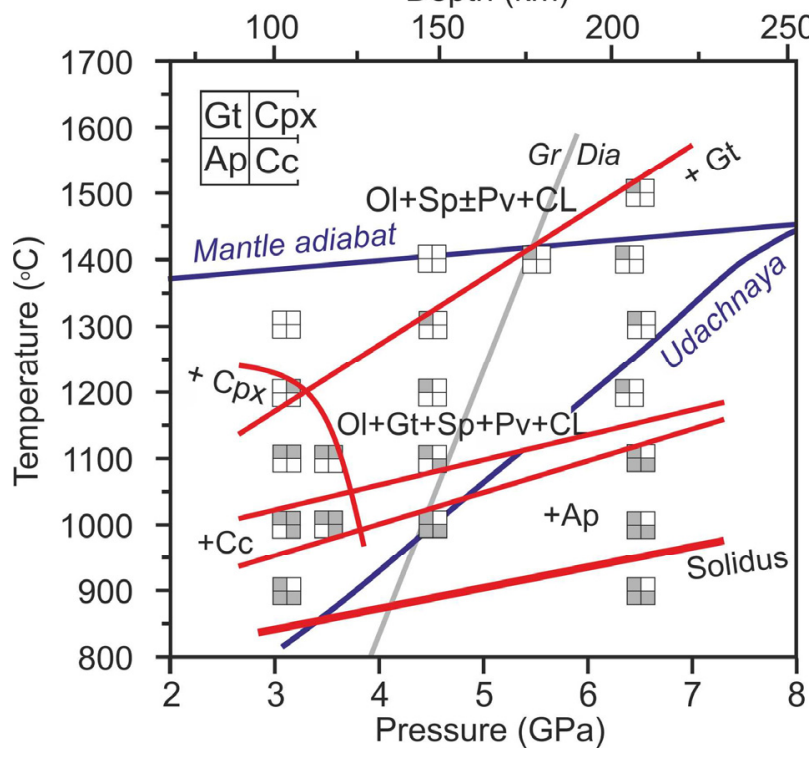

Fig. 2. Experimental phase diagram of UEK kimberlite. Ol - olivine; $\mathrm{Sp}-$ Al-spinel, $\mathrm{Pv}$ - perovskite, $\mathrm{Gt}$ - garnet; $\mathrm{Cpx}$ - clinopyroxene; Ap - apatite; $\mathrm{Cc}, \mathrm{Ca}$-carbonate, $\mathrm{CL}$ - carbonatite melt. Blue lines show mantle adiabat and Udachnaya geotherm from McKenzie et al. (2005). Graphite-diamond (Gr-Dia) transition line is shown for comparison.
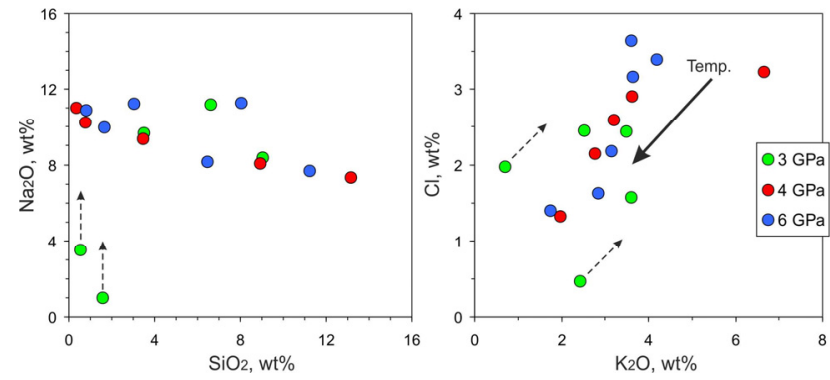

Fig. 3. Composition of partial melts from UEK experiments. Arrows show underestimated alkali and chlorine contents possibly due to loss during sample polishing and storage.

magnesite, apatite, and aragonite (Fig. 5-6). Phlogopite is stable below $4 \mathrm{GPa}$ and $1100^{\circ} \mathrm{C}$. Solidus temperatures were determined at $<900^{\circ} \mathrm{C}(2-3 \mathrm{GPa}),<950^{\circ} \mathrm{C}(4.5 \mathrm{GPa})$, and $950^{\circ} \mathrm{C}(6.5 \mathrm{GPa})$. Possible stability of alkali chlorides above the solidus is not clear (Fig. 5). Presumably subsolidus sylvite, halite, fluorite, and $\mathrm{CaCl}_{2}$ crystals were observed at 900- $1000^{\circ} \mathrm{C}$. Cl-bearing brine was observed at $3 \mathrm{GPa}$ and $900^{\circ} \mathrm{C}$. They are enriched by $\mathrm{Fe}, \mathrm{Ca}, \mathrm{Na}$, and $\mathrm{K}$. It was possible to polish this brine, but it was easily destroyed by electron beam.

The solidus temperature ranges from 940 to $980^{\circ} \mathrm{C}$ at 2.1 GPa, from 860 to $900^{\circ} \mathrm{C}$ at $3.1 \mathrm{GPa}$, and from 930 to $970^{\circ} \mathrm{C}$ at $6.5 \mathrm{GPa}$. At $2.1 \mathrm{GPa}$ and $900^{\circ} \mathrm{C}$ numerous bubbles of fluid enriched in $\mathrm{CO}_{2}$ were observed in the sample. The bend of the solidus line at a pressure of $\sim 2.5 \mathrm{GPa}$ typical for carbonate systems is controlled by the decarbonation reactions and release of free $\mathrm{CO}_{2}$.

Table 1. Selected compositions of starting UEK and quenched melts after experiments ( $\mathrm{wt} \%)$.

\begin{tabular}{lccccccc}
\hline $\mathrm{P}, \mathrm{GPa}$ & & 3.1 & 3.1 & 4.5 & 4.5 & 6.5 & 6.5 \\
$\mathrm{~T},{ }^{\circ} \mathrm{C}$ & $\mathrm{UEK}$ & 1000 & 1200 & 1100 & 1300 & 1200 & 1400 \\
\hline $\mathrm{SiO}_{2}$ & 25.9 & 1.58 & 6.62 & 0.76 & 8.90 & 1.67 & 6.48 \\
$\mathrm{TiO}_{2}$ & 1.81 & 0.81 & 0.53 & 0.08 & 0.72 & 0.15 & 0.90 \\
$\mathrm{Al}_{2} \mathrm{O}_{3}$ & 2.79 & 0.37 & 0.43 & 0.01 & 0.60 & 0.06 & 0.37 \\
$\mathrm{Cr}_{2} \mathrm{O}_{3}$ & 0.15 & 0.00 & 0.01 & 0.00 & 0.08 & 0.00 & 0.02 \\
$\mathrm{FeO}$ & 8.97 & 4.25 & 3.25 & 1.50 & 3.72 & 2.47 & 3.64 \\
$\mathrm{MnO}$ & 0.16 & 0.45 & 0.13 & 0.19 & 0.16 & 0.16 & 0.22 \\
$\mathrm{MgO}$ & 30.1 & 8.17 & 5.70 & 5.30 & 7.58 & 7.95 & 10.2 \\
$\mathrm{CaO}$ & 12.7 & 25.1 & 30.7 & 31.3 & 27.8 & 27.1 & 27.0 \\
$\mathrm{Na}_{2} \mathrm{O}$ & 3.44 & 10.1 & 11.2 & 10.2 & 8.06 & 9.97 & 8.15 \\
$\mathrm{~K}_{2} \mathrm{O}$ & 1.31 & 0.70 & 3.49 & 3.62 & 2.76 & 3.64 & 2.84 \\
$\mathrm{P}_{2} \mathrm{O}_{5}$ & 0.95 & 0.88 & 2.48 & 3.10 & 2.56 & 2.66 & 2.42 \\
$\mathrm{SO}_{3}$ & 0.28 & 0.16 & 1.29 & 0.98 & 0.57 & 0.92 & 0.42 \\
$\mathrm{Cl}$ & 0.85 & 1.97 & 2.43 & 2.90 & 2.15 & 3.16 & 1.62 \\
$\mathrm{~F}$ & 0.15 & 0.57 & 0.53 & 0.96 & 0.85 & 1.21 & 0.89 \\
$\mathrm{H}_{2} \mathrm{O}^{*}$ & 0.5 & 1.9 & 1.5 & 1.5 & 1.3 & 1.6 & 1.4 \\
$\mathrm{CO}_{2} *$ & 10.8 & 37.0 & 32.0 & 33.0 & 28.5 & 34.0 & 29.5 \\
$\mathrm{~F}, \%$ & & 0.26 & 0.34 & 0.33 & 0.38 & 0.32 & 0.37 \\
\hline
\end{tabular}

*calculated from mass-balance, $\mathrm{F}$ - degree of melting. 


\section{$10^{\text {th }}$ International Kimberlite Conference, Bangalore - 2012}

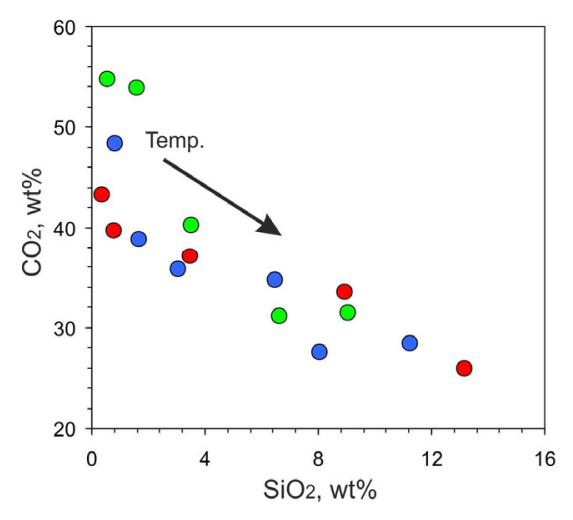

Fig.4. $\mathrm{SiO}_{2}-\mathrm{CO}_{2}$ plot for partial melts from UEK experiments. Arrows show temperature increase trend. Symbols are as in Fig.2.
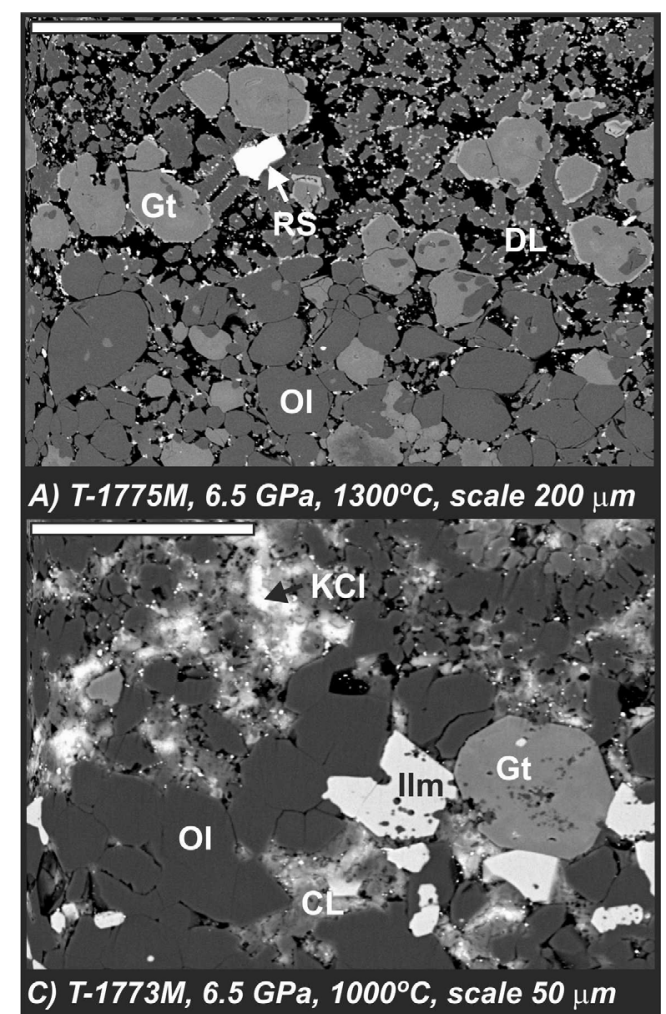

Fig. 5. Back-scattered electron images of CDK samples after experiments. A) Partial melting zone of olivine (Ol), garnet (Gt) and dolomitic melt (DL), RS - minor $\mathrm{ReS}_{2}$ crystals. B) nearsolidus experiments containing olivine, garnet, ilmenite (Ilm) and chloride $(\mathrm{KCl})$ crystals with minor carbonatite melt (CL).

At 6.5 GPa low-temperature garnets are enriched in $\mathrm{CaO}$ (22-24 wt\%) and $\mathrm{P}_{2} \mathrm{O}_{5}$ (up to $1.6 \mathrm{wt} \%$ ). The concentration of $\mathrm{TiO}_{2}$ in garnets increases with temperature reaching 5 $\mathrm{wt} \%$ at temperatures above the ilmenite stability. The concentration of $\mathrm{Cr}_{2} \mathrm{O}_{3}$ does not exceed 2.5 wt \%. Clinopyroxene has variable $\mathrm{Al}_{2} \mathrm{O}_{3}$ contents, which strongly decreases with pressure from $8-10 \mathrm{wt} \%$ to $2.3 \mathrm{wt} \%$ and depends on garnet stability. Clinopyroxene also contains (wt\%) 0.2-3.0 $\mathrm{TiO}_{2}$ (increase with temperature), 0.2-0.5 $\mathrm{Cr}_{2} \mathrm{O}_{3}, 1.0-1.5 \mathrm{Na}_{2} \mathrm{O}$, and $<0.1 \mathrm{~K}_{2} \mathrm{O}$. Ilmenite contains $16-$ $22 \mathrm{wt} \% \mathrm{MgO}$ that exceeds the concentrations in natural samples (6-16 wt \%).

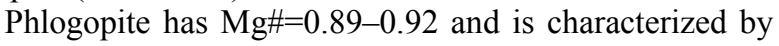
high $(3-5 \mathrm{wt} \%)$ concentrations of $\mathrm{TiO}_{2}$. It is important to note that, in spite of the high chlorine concentration in the system, phlogopite contains only $0.4-0.7 \mathrm{wt} \% \mathrm{Cl}$, but 1.0 $1.8 \mathrm{wt} \% \mathrm{~F}(0.5 \mathrm{wt} \% \mathrm{~F}$ in starting mixture). Thus, low concentrations of chlorine in phlogopites from the groundmass of kimberlite, as well as from xenoliths of the Udachnaya pipe (0-0.2 wt\%) (Golovin et al., 2007) do not contradict the high concentrations of chlorine in primary kimberlitic melt, because even at a concentration of 5-10 wt $\% \mathrm{Cl}$ in the coexisting melt, phlogopite contains $<0.7 \mathrm{wt} \%$ $\mathrm{Cl}$ in the studied CDK system.

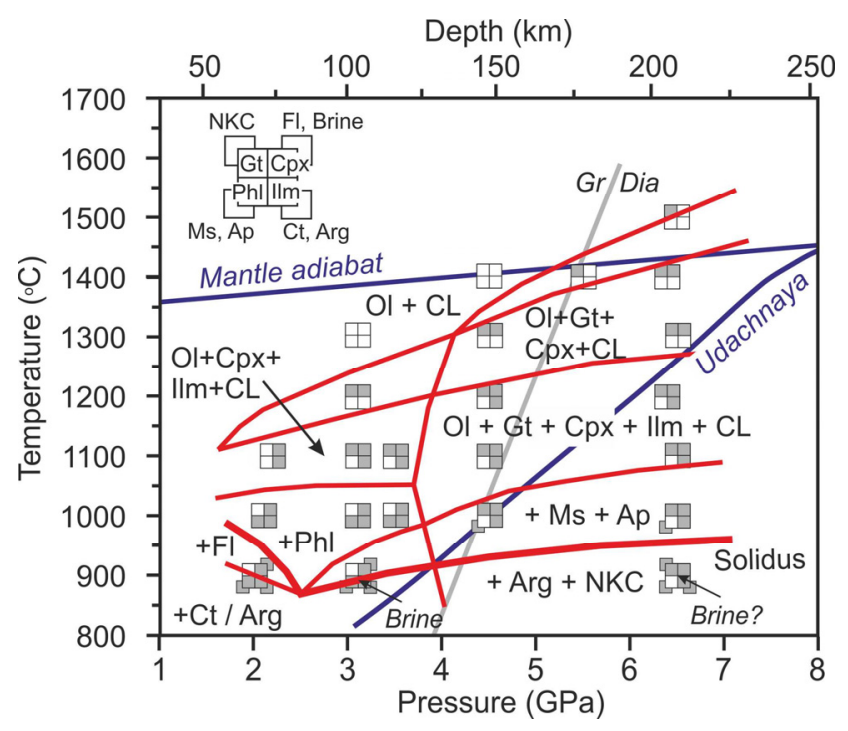

Fig. 6. Experimental phase diagram of CDK kimberlite. Ol - olivine; Gt garnet; Cpx - clinopyroxene; Ilm - ilmenite; $\mathrm{Phl}$ - phlogopite, Mst magnesite; Ap - apatite; Arg - Aragonite, Ct - calcite; NKC - chloride; CL - carbonatite melt. Other lines are as in Fig. 2.

All compositions of partial melt at 3-6 GPa can be considered as carbonatitic $\left(<14 \mathrm{wt} \% \mathrm{SiO}_{2}\right)$ and are close to dolomitic carbonatite (Fig. 7). The melts have relatively low alkali and high $\mathrm{Cl}$ contents (wt\%): $\mathrm{Na}_{2} \mathrm{O}=1.5-3.3, \mathrm{~K}_{2} \mathrm{O}=$ 1.2-3.8, $\mathrm{Cl}=2.1-7.4$. Phlogopite strongly controls the composition of partial melt and drastically reduces its $\mathrm{K}_{2} \mathrm{O}$ content (Fig. 7). As is evident from relationships between chlorine and alkalis in melts, significant amount of chlorine may be linked to calcium; i.e., calcium may be associated to chlorine, but not the carbonate-ion in the melt. All melts at 3.1, 4.5, and $6.5 \mathrm{GPa}$ form a similar temperature trends from chlorine-rich carbonate to chlorine-depleted carbonate-silicate melts. Melts of high melting degrees 


\section{$10^{\text {th }}$ International Kimberlite Conference, Bangalore - 2012}

correspond to the compositions of the carbonate-silicate series of inclusions in diamonds (Litasov et al., 2010b).

The kimberlite-carbonate-chloride system with a high concentration of chlorides and carbonates was studied in Safonov et al. (2009) at $4.8 \mathrm{GPa}$ and $1400-1600^{\circ} \mathrm{C}$. The higher chlorine concentration in the system results in liquid immiscibility in the melt onto chloride-carbonate and carbonate-silicate liquids (Fig. 8). The composition of the latter corresponds to the compositions of melts in the CDK system.
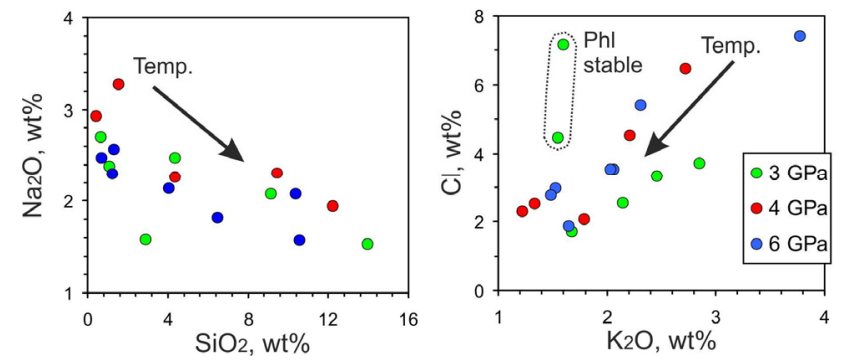

Fig. 7. Composition of partial melts from CDK experiments. Arrows show temperature increase trends.

\section{DISCUSSION}

Phase relations in $\mathrm{Cl}$-free kimberlitic systems were considered in (Edgar et al., 1988; Edgar, Charbonneau, 1993; Girnis et al., 1995; Ulmer and Sweeney, 2002). The composition of silica-undersaturated aphanitic kimberlite (group I) of the Vesselton pipe (South Africa), the closest to the Udachnaya pipe kimberlite (Edgar et al., 1988; Edgar, Charbonneau, 1993), was studied in up to pressures of 10 $\mathrm{GPa}$. Olivine and garnet were the liquidus phases following by $\mathrm{Mg}-\mathrm{Al}-\mathrm{Fe}-\mathrm{Ti}-\mathrm{Cr}$ spinels of various compositions, whereas apatite and calcite/aragonite were observed up to a temperature of $1600^{\circ} \mathrm{C}$ at $6 \mathrm{GPa}$. Comparison of phase relationships of chlorine-bearing kimberlite with kimberlites of group II (Ulmer and Sweeney, 2002) provides evidence for the absence of orthopyroxene at the expense of the lower $\mathrm{SiO}_{2}$ in the system, expansion of the clinopyroxene stability field towards higher temperatures, and narrowing of the phlogopite stability field towards lower temperatures. The latter is controlled by the lower concentration of water in our systems.

The phase relationships obtained and the compositions of minerals and melts indicate that kimberlite of the Udachnaya pipe was not in equilibrium with mantle peridotites in the magma formation area. The composition of minerals in olivine + garnet + clinopyroxene \pm ilmenite restite in $\mathrm{CDK}$ or olivine + garnet \pm spinel \pm perovskite does not have analogues among mantle rocks. An association of garnet + clinopyroxene \pm ilmenite with the compositions of minerals obtained in runs may correspond to some magmatic eclogites, the varieties of which are abundant among xenoliths of the Udachnaya pipe.
However, olivine, spinel and perovskite would be first crystallizing from kimberlite melt according to study of natural samples (Golovin et al., 2007). The Ca-rich compositions of garnet in the both UEK and CDK systems do not have analogues among the natural samples.

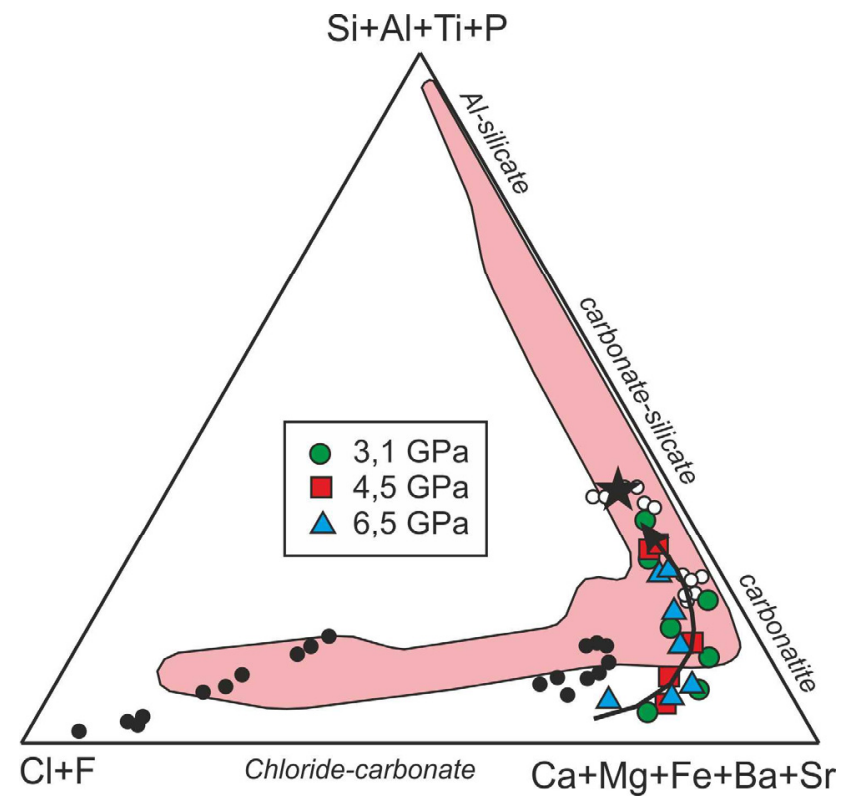

Fig. 8. Composition of melts in CDK system in comparison with the composition of inclusions in diamonds (pink field after Safonov et al., 2007). The arrow indicates the trend of the evolution of melt composition with increase of the degree of melting. The asterisk demonstrates the starting composition of CDK. White circles - UEK system. Black circles show the compositions of immiscible melts from runs in the kimberlitecarbonate-chloride system at 4.8 GPa (Safonov et al., 2009).

Estimated PT-profiles for kimberlite magma ascent do not exceeds average mantle adiabat, ca. $1400^{\circ} \mathrm{C}$ at $6 \mathrm{GPa}$ (Fig. 9). At these temperatures $\mathrm{SiO}_{2}$-saturation of parental kimberlite melt does not exceed 5-10 wt \% at $6 \mathrm{GPa}$ in $\mathrm{H}_{2} \mathrm{O}-$ free or $\mathrm{H}_{2} \mathrm{O}$-poor systems. Extrapolation of our data for UEK to $1600^{\circ} \mathrm{C}$ and $6 \mathrm{GPa}$ indicate that even at these parameters $\mathrm{SiO}_{2}$ content of the partial melt does not exceed $20 \mathrm{wt} \%$.

Most likely the primary melt during the formation of kimberlite of the Udachnaya pipe had a chloride-carbonate composition with a small amount of $\mathrm{SiO}_{2}(<20 \mathrm{wt} \%)$. Enrichment in silica and magnesia could occur during the reaction of the carbonatite melt with orthopyroxene (to a lesser degree, clinopyroxene and olivine) from captured fragments of peridotite during magma ascent to the surface. However, the kinetics of this process has not been studied yet. An addition of $\mathrm{Cl}$ and $\mathrm{H}_{2} \mathrm{O}$ to the system shifts partial melt compositions towards $\mathrm{Mg}$-rich dolomitic carbonatite. Mass balance calculations indicate that original UdachnayaEast kimberlite magma was mixture of xenoliths (55-75 


\section{$10^{\text {th }}$ International Kimberlite Conference, Bangalore - 2012}

$\mathrm{wt} \%$ ) and carbonatite melt along the PT-pathway of magma ascent.

The mantle substrate, which underwent melting, represents metasomatized mantle, most likely of duniteharzburgite composition (with a low pyroxene concentration). Subducting oceanic crust or oceanic sediments may be a source of chlorine and carbonates for a metasomatizing agent in the mantle; however, this still remains at the level of assumptions.

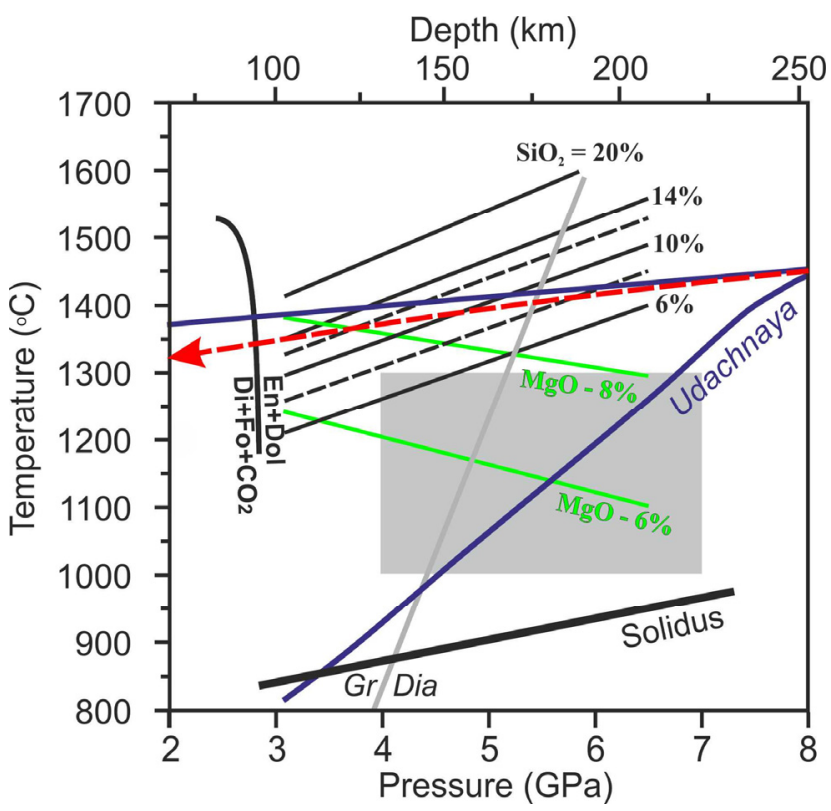

Fig. 9. PT-diagram, which shows possible evolution of carbonatitekimberlite melt of Udachnaya pipe. Lines show approximate equilibrium concentrations of $\mathrm{SiO}_{2}$ and $\mathrm{MgO}$ in the melt from UEK experiments. Red arrow shows model of kimberlite magma adiabatic accent after Kavanagh and Sparks (2009). Decarbonation reaction curve (En+Dol) is after Eggler (1978). Grey field show approximate PT-estimations from mantle xenoliths. Other lines are as in Fig. 2.

\section{ACKNOWLEDGMENTS}

This study was supported by Global Center of Excellence Program "Advanced Science and Technology Center for the Dynamic Earth" at Tohoku University and the Russian Foundation for Basic Research (no. 09-0500917 and 10-05-0575).

\section{REFERENCES}

Edgar, A.D., Arima, M., Baldwin, D.K., Bell, D.R., Shee, S.R., Skinner, E.M.W., Walker, E.C. (1988). High-pressure high-temperature melting experiments on $\mathrm{SiO}_{2}$-poor aphanific kimberlite from the Wesselton mine, Kimberley, South Africa. American Mineralogist 73, 524-533.

Edgar, A.D., Charbonneau, H.E. (1993). Melting experiments on a $\mathrm{SiO}_{2}$ poor, Ca-rich aphanitic kimberlite from 5-10 GPa and the bearing on sources of kimberlite magmas. American Mineralogist 78, 132-142.

Eggler, D.H. (1978). Effect of $\mathrm{CO}_{2}$ upon partial melting of peridotite in system $\mathrm{Na}_{2} \mathrm{O}-\mathrm{CaO}-\mathrm{Al}_{2} \mathrm{O}_{3}-\mathrm{MgO}-\mathrm{SiO}_{2}-\mathrm{CO}_{2}$ to $35 \mathrm{~kb}$ with an analysis of melting in a peridotite- $\mathrm{H}_{2} \mathrm{O}-\mathrm{CO}_{2}$ system. American Journal of Science 278, 305-343.
Girnis, A.V., Brey, G.P., Ryabchikov, I.D. (1995). Origin of group 1A kimberlites: Fluid-saturated melting experiments at 45-55 kbars. Earth and Planetary Science Letters 134, 283-296.

Golovin, A.V., Sharygin, V.V., Pokhilenko, N.P. (2007). Melt inclusions in olivine phenocrysts in unaltered kimberlites from the UdachnayaEast pipe, Yakutia: Some aspects of kimberlite magma evolution during late crystallization stages. Petrology 15, 168-183.

Izraeli, E.S., Harris, J.W., Navon, O. (2004). Fluid and mineral inclusions in cloudy diamonds from Koffiefontein, South Africa. Geochimica et Cosmochimica Acta 68, 2561-2575.

Kamenetsky, M.B., Sobolev, A.V., Kamenetsky, V.S., Maas, R., Danyushevsky, L.V., Thomas, R., Pokhilenko, N.P., Sobolev, N.V. (2004). Kimberlite melts rich in alkali chlorides and carbonates: A potent metasomatic agent in the mantle. Geology 32, 845-848.

Kamenetsky, V.S., Kamenetsky, M.B., Sharygin, V.V., Golovin, A.V. (2007). Carbonate-chloride enrichment in fresh kimberlites of the Udachnaya-East pipe, Siberia: A clue to physical properties of kimberlite magmas? Geophysical Research Letters 34, L09316, 09310.01029/02007gl029389.

Kavanagh, J.L., Sparks, R.S.J. (2009). Temperature changes in ascending kimberlite magma. Earth and Planetary Science Letters 286, 404-413.

Klein-BenDavid, O., Izraeli, E.S., Hauri, E., Navon, O., 2004. Mantle fluid evolution - a tale of one diamond. Lithos 77, 243-253.

Litasov, K.D., Ohtani, E. (2009). Phase relations in the peridotitecarbonate-chloride system at 7.0-16.5 GPa and the role of chlorides in the origin of kimberlite and diamond. Chemical Geology 262, 29-41.

Litasov, K.D., Ohtani, E. (2010). The solidus of carbonated eclogite in the system $\mathrm{CaO}-\mathrm{Al}_{2} \mathrm{O}_{3}-\mathrm{MgO}-\mathrm{SiO}_{2}-\mathrm{Na}_{2} \mathrm{O}-\mathrm{CO}_{2}$ to $32 \mathrm{GPa}$ and carbonatite liquid in the deep mantle. Earth and Planetary Science Letters 295, $115-126$.

Litasov, K.D., Safonov, O.G., Ohtani, E. (2010a). Origin of Cl-bearing silica-rich melt inclusions in diamonds: Experimental evidence for an eclogite connection. Geology 38, 1131-1134.

Litasov, K.D., Sharygin, I.S., Shatskiy, A.F., Ohtani, E., Pokhilenko, N.P. (2010b). Experimental constraints on the role of chloride in the origin and evolution of kimberlitic magma. Doklady Earth Sciences 435, 1641-1646.

McKenzie, D., Jackson, J., Priestley, K. (2005). Thermal structure of oceanic and continental lithosphere. Earth and Planetary Science Letters 233, 337-349.

Safonov, O.G., Perchuk, L.L., Litvin, Y.A. (2007). Melting relations in the chloride-carbonate-silicate systems at high-pressure and the model for formation of alkalic diamond-forming liquids in the upper mantle. Earth and Planetary Science Letters 253, 112-128.

Safonov, O.G., Perchuk, L.L., Yapaskurt, V.O., Litvin, Y.A. (2009). Immiscibility of carbonate-silicate and chloride-carbonate melts in the kimberlite- $\mathrm{CaCO}_{3}-\mathrm{Na}_{2} \mathrm{CO}_{3}-\mathrm{KCl}$ system at $4.8 \mathrm{GPa}$. Doklady Earth Sciences 424, 142-146.

Ulmer, P., Sweeney, R.J. (2002). Generation and differentiation of group II kimberlites: Constraints from a high-pressure experimental study to 10 GPa. Geochimica et Cosmochimica Acta 66, 2139-2153. 